\title{
Differences in Evaluation of Corporate Training from the Viewpoint of the Work Position and Sector
}

\author{
Zuzana Birknerová, Miroslav Frankovský, Mária Zahatňanská, Lucia Zbihlejová \\ University of Prešov in Prešov, Slovakia
}

\begin{abstract}
The contemporary knowledge society should consist of components based on knowledge, creativity and information. Reaching such level of organizations assumes a priority position of ongoing education as a natural, planned and directed part of life of any organization. Effectiveness of education in organizations is conditioned by a wide range of internal and external factors. The presented study focuses on education evaluation, particularly analysis of possibilities of determining the effectiveness of corporate training. It presents the results of verification of an own methodology SBES (Significance, Benefits, Expectations and Satisfaction), which enables specification of several indicators of corporate training evaluation. The Principal Component Analysis with Varimax rotation was used to extract and specify four factors: Relevance to the profession, Benefits for employees, Employee expectations, Employee satisfaction. The study also describes the specific practical application of this methodology in the context of identification and specification of the differences in evaluation of corporate training between managers and non-managerial workers, and between employees of the private and the public sector. Presented findings support the claim that managers and the public sector employees have a more intense perception of the need, significance and importance of corporate training, which is closely connected to their work, career advancement, higher financial remuneration, and interpersonal relations.
\end{abstract}

\section{Introduction}

Labor market success as well as the quality and performance at work are conditioned, besides other factors, by an adequate degree of education. Achieving this degree is related also to the feeling of satisfaction with the employment status [1].

In this context it is crucial to highlight the fact that education is a tool, not a goal. In order for an organization to be successful, it needs to invest in meaningful education of its employees not only financially, but also time-wise. Corporate training must be a reaction to the social changes because people are becoming more demanding, critical, educated and fastidious [2].
High organizational performance is contingent on the development of competences and selfmanagement of employees [3]. Staff performance may be increased not only by their evaluation and remuneration, but also their development.

According to Fitzgerald [4], staff development means:

- acquisition of knowledge and skills which may be used both at present and in the future,

- preparation of individuals in order for them to enrich the organization in the future,

- involvement in various educational activities.

The key factor in development of any organization is its employees. Their development is inevitable for taking on new challenges, long-term health and viability of the organization. Staff development places the organization in a position where it may face the changes directly. In fact, the developed work force does not react to the change but rather creates it itself [4].

Savery and Luks [5] conducted a research by which they managed to prove the connection between the increased resources invested in education and the increased productivity and operating profit, which is supported by an opinion that education represents investment into the work force that is highly viable and thus also valuable for the organization.

Education may be one of the options of resolving the problems of the organization which prevent it from implementation of its objectives [6].

\section{Effective Education and Employee Development}

If an organization wants to make a progress, it is inevitable to focus on education of its employees. This education may have a different nature, degree and intensity in accordance with the needs of the organization [7].

Effective education is characterized by being well prepared and organized, systematic, and continuous within a repetitive cycle [8]. To ensure a smooth and trouble-free fulfillment of the program of education and training, it is, according to Vodák and Kucharčíková [9], important to: 
- make sure that all participants have an opportunity to comment on all parts of the program at its beginning,

- have the participants express their expectations of the course (advantage: additional amendments to the program and topics required by the participants - the participants are therefore motivated and capable of quick identification with the goals),

- sign a so-called contract at the beginning (it is a confirmation or adjustment of the program to satisfy the expectations of all participants and lecturers as well, a mutual agreement),

- have the lecturers during an educational activity provide a sufficient time reserve for final implementation of activities aimed at a thorough revision of what has been covered in the course of this activity and comparison of expectations of the participants at the beginning and at the end of the training.

Feedback on the effectiveness of the training is one of the most important parts of the whole educational cycle. By its means it is possible to assess the degree of effectiveness of any educational program and its manifestations in the work process.

Evaluation of educational activities is dominated by satisfaction surveys as they are measured more easily and more quickly than the impact of educational activities on the results which are usually multidimensional. Evaluation of educational activities represents a balance between something that is subjective, as the evaluation of satisfaction, and something that is factual or objective but related to the educational activity [10].

\section{Research}

\subsection{Research Sample}

The research sample consisted of employees from both the public and the private sectors working in the areas of production, administration and education. Addressed were 152 respondents out of which 87 were male $(57.2 \%)$ and 65 were female $(42.8 \%)$ aged from 21 to 62 years (average age of 40.84 years, standard deviation of 10.51 years). Out of the addressed respondents, 92 work in the private sector $(60.5 \%), 60$ work in the public sector $(39.5 \%), 62$ of them are managers $(40.8 \%)$ and 90 are non-managers or efficient workers (59.2\%). There were 51 production employees $(33.6 \%), 36$ administration employees (23.7\%), 21 education employees (13.8\%), and 44 respondents employed in other work areas $(28.9 \%)$. The number of years of service was in the range of 1 to 44 years, whereas the average number was 17.36 years of service (standard deviation of 10.806 years).

\subsection{Method}

Effectiveness of corporate training was detected by an own original methodology labeled as SBES (Significance, Benefits, Expectations and Satisfaction; originally: VVOS = Význam, Výhody, Očakávania a Spokojnost'). This questionnaire consists of 22 items on the basis of which the respondents assessed various aspects of corporate training. The individual items were evaluated on a 5point scale, where $1=$ certainly no, $2=$ rather no, $3=$ neither no, nor yes, $4=$ rather yes, $5=$ certainly yes.

\subsection{Results}

The Principal Component Analysis with Varimax Rotation was used to extract 4 factors the content of which may be described as follows:

F1: Significance for the profession. Respondents scoring high in this factor attach greater importance to education for the profession; they perceive a greater personal significance of education and see higher degree of relation to the work performance.

F2: Benefits for the employees. Respondents with higher scores in this factor attach greater importance to education for career development, positive evaluation, improvement of relationships on the workplace, and for motivation increase.

F3: Expectations of the employees. Respondents scoring high in this factor provide positive evaluation of the education program, utilized methods and forms of education and the training course, and have also higher expectations.

F4: Satisfaction of the employees. Respondents with higher scores in this factor evaluate education as more comprehensible, acceptable, and adequate time-wise.

The extracted factors explain $65.6 \%$ of variance (see Table 1). Acceptability of the extracted factors is confirmed also by the Cronbach's alpha values (see Table 2).

Practical application of this methodology in the context of identification and specification of the differences in evaluation of corporate training between managers and non-managers, as well as the public and the private sector employees, was also carried out. The correlation analysis confirmed statistically significant correlations between the individual extracted factors (see Table 3). 
Table 1. Saturation of extracted factors by individual items of methodology for corporate training assessment

\begin{tabular}{|c|c|c|c|c|}
\hline \multirow[b]{2}{*}{ Questionnaire items } & \multicolumn{4}{|c|}{ Factors } \\
\hline & F1 & $\mathrm{F} 2$ & F3 & F4 \\
\hline Do you educate yourself in addition to your work? & .654 & & & \\
\hline Is further education important in your profession? & .730 & & & \\
\hline Is your further education important for you? & .692 & & & \\
\hline $\begin{array}{l}\text { Is the content of further education related to your } \\
\text { work? }\end{array}$ & .778 & & & \\
\hline $\begin{array}{l}\text { Does your further education bring you any benefits at } \\
\text { work? }\end{array}$ & & .566 & & \\
\hline $\begin{array}{l}\text { Does your further education influence your career } \\
\text { advancement? }\end{array}$ & & .743 & & \\
\hline $\begin{array}{l}\text { Are you evaluated at work also in accordance with } \\
\text { your education? }\end{array}$ & & .696 & & \\
\hline $\begin{array}{l}\text { Does further education enhance the relations at the } \\
\text { workplace? }\end{array}$ & & .669 & & \\
\hline Does your employer motivate you to further education? & & .698 & & \\
\hline $\begin{array}{l}\text { Does your organization provide an elaborated } \\
\text { educational program for its employees? }\end{array}$ & & & .451 & \\
\hline $\begin{array}{l}\text { Is your further education carried out during the } \\
\text { working hours? }\end{array}$ & & & & .746 \\
\hline $\begin{array}{l}\text { Are you satisfied with the education provided by your } \\
\text { organization? }\end{array}$ & & & & .587 \\
\hline $\begin{array}{l}\text { Is the educational method clear and comprehensible to } \\
\text { you? }\end{array}$ & & & & .565 \\
\hline $\begin{array}{l}\text { Is your further education connected to the financial } \\
\text { evaluation? }\end{array}$ & & .667 & & \\
\hline Does your employer accept your further education? & & & & .613 \\
\hline $\begin{array}{l}\text { Do you know who is in your organization responsible } \\
\text { for the further education of employees? }\end{array}$ & & & & .479 \\
\hline $\begin{array}{l}\text { If you are being further educated, have you been } \\
\text { provided with any study texts? }\end{array}$ & & & .749 & \\
\hline $\begin{array}{l}\text { Are you satisfied with the methods and forms of } \\
\text { education? }\end{array}$ & & & .543 & \\
\hline $\begin{array}{l}\text { Have your ideas and expectations of education been } \\
\text { met? }\end{array}$ & & & .688 & \\
\hline $\begin{array}{l}\text { Is your further education carried out also by means of } \\
\text { e-learning? }\end{array}$ & & & .787 & \\
\hline $\begin{array}{l}\text { Does your education include also communication } \\
\text { training? }\end{array}$ & & & .749 & \\
\hline Is your education voluntary? & .764 & & & \\
\hline Eigenvalue & 9.99 & 1.75 & 1.60 & 1.07 \\
\hline$\%$ of Variance & 45.42 & 7.98 & 7.31 & 4.88 \\
\hline
\end{tabular}

Table 2. Cronbach's alpha values for defined methodology factors 


\begin{tabular}{|c|c|c|c|c|}
\hline \multirow{2}{*}{ Cronbach's alpha } & F1 & F2 & F3 & F4 \\
\cline { 2 - 5 } & .899 & .884 & .860 & .771 \\
\hline
\end{tabular}

Table 3. Links between individual methodology factors

\begin{tabular}{|c|c|c|c|c|}
\hline & F1 & F2 & F3 & F4 \\
\hline F1 & - & $.664^{* *}$ & $.649^{* *}$ & $.551^{* *}$ \\
\hline F2 & $.664^{* *}$ & - & $.602^{* *}$ & $.682^{* *}$ \\
\hline F3 & $.649^{* *}$ & $.602^{* *}$ & - & $.637^{* *}$ \\
\hline F4 & $.551^{* *}$ & $.682^{* *}$ & $.637^{* *}$ & - \\
\hline
\end{tabular}

** statistical significance level of 0.01

3.3.1. Differences in evaluation of corporate training from the viewpoint of the work position. As the comparison results provided in Table 4 illustrate, significant differences between the managers and the non-managers in all four analyzed factors of corporate training were identified, whereas in all cases the managers scored higher than the efficient workers.

Table 4. Comparison of corporate training assessment by managers and non-managers

\begin{tabular}{|c|c|c|c|c|}
\hline Factors & Work position & Mean & t-test & $\mathrm{p}$ \\
\hline \multirow{2}{*}{ F1 } & Managers & 3.78 & \multirow{2}{*}{3.001} & \multirow{2}{*}{.003} \\
\hline & Non-managers & 3.14 & & \\
\hline \multirow{2}{*}{$\mathrm{F} 2$} & Managers & 3.40 & \multirow{2}{*}{3.174} & \multirow{2}{*}{.002} \\
\hline & Non-managers & 2.81 & & \\
\hline \multirow{2}{*}{ F3 } & Managers & 3.44 & \multirow{2}{*}{3.836} & \multirow{2}{*}{.000} \\
\hline & Non-managers & 2.71 & & \\
\hline \multirow{2}{*}{ F4 } & Managers & 3.67 & \multirow{2}{*}{3.998} & \multirow{2}{*}{.000} \\
\hline & Non-managers & 2.95 & & \\
\hline
\end{tabular}

$\mathrm{p}$ - statistical significance

Subsequently, an analysis was performed to find statistically significant differences in the individual items of evaluation of corporate training from the viewpoint of the work position (see Table 5 and Figure 1).

The presented findings confirm that managers have a more intense perception of the need, significance and importance of the corporate training, which is closely related to their work, career advancement, higher financial remuneration and interpersonal relations.

Expectations and satisfaction of managers with the corporate training closely correspond with the program and course of the training, utilized methods and forms, and its clarity. They are interested in educational communication trainings as well as elearning. They are also more flexible and seek education voluntarily.

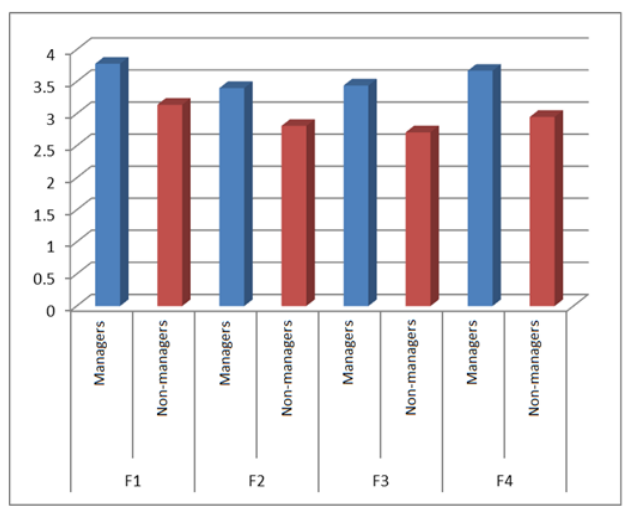

Figure 1. Average values of factor evaluation from the viewpoint of the work position

3.3.2. Differences in evaluation of corporate training from the viewpoint of the public and the private sector. Following the presented findings, another analysis was performed to find differences in evaluation of the individual items and factors of corporate training assessment from the perspective of the public and the private sector (see Table 6 and Figure 2). Illustrated are only those items and factors, which displayed statistically significant differences between the public sector employees and the private sector employees. 
Table 5. Comparison of evaluation of corporate training from the viewpoint of the work position

\begin{tabular}{|c|c|c|c|c|c|}
\hline Q. items & Work position & Mean & Standard dev. & Test crite-rion & $\mathrm{p}$ \\
\hline \multirow[b]{2}{*}{ Q1 } & Managers & 3.59 & 1.411 & \multirow[b]{2}{*}{2.438} & \multirow[b]{2}{*}{.016} \\
\hline & Non-managers & 3.00 & 1.152 & & \\
\hline \multirow[b]{2}{*}{ Q2 } & Managers & 3.78 & 1.362 & \multirow[b]{2}{*}{2.177} & \multirow[b]{2}{*}{.031} \\
\hline & Non-managers & 3.24 & 1.193 & & \\
\hline \multirow[b]{2}{*}{ Q3 } & Managers & 3.84 & 1.221 & \multirow[b]{2}{*}{2.342} & \multirow[b]{2}{*}{.021} \\
\hline & Non-managers & 3.29 & 1.171 & & \\
\hline \multirow{2}{*}{ Q4 } & Managers & 3.91 & 1.353 & \multirow{2}{*}{2.767} & \multirow{2}{*}{.006} \\
\hline & Non-managers & 3.18 & 1.295 & & \\
\hline \multirow{2}{*}{ Q5 } & Managers & 3.81 & 1.091 & \multirow{2}{*}{3.752} & \multirow[b]{2}{*}{.000} \\
\hline & Non-managers & 2.99 & 1.091 & & \\
\hline \multirow{2}{*}{ Q7 } & Managers & 3.31 & 1.281 & \multirow{2}{*}{2.529} & \multirow[b]{2}{*}{.013} \\
\hline & Non-managers & 2.71 & 1.155 & & \\
\hline \multirow{2}{*}{ Q8 } & Managers & 3.59 & 1.103 & \multirow[b]{2}{*}{3.519} & \multirow[b]{2}{*}{.001} \\
\hline & Non-managers & 2.83 & 1.078 & & \\
\hline \multirow{2}{*}{ Q9 } & Managers & 3.47 & 1.344 & \multirow[b]{2}{*}{3.099} & \multirow[b]{2}{*}{.002} \\
\hline & Non-managers & 2.67 & 1.274 & & \\
\hline \multirow{2}{*}{ Q10 } & Managers & 3.38 & 1.497 & \multirow{2}{*}{2.268} & \multirow{2}{*}{.025} \\
\hline & Non-managers & 2.85 & 1.046 & & \\
\hline \multirow{2}{*}{ Q11 } & Managers & 3.41 & 1.103 & \multirow[b]{2}{*}{2.520} & \multirow[b]{2}{*}{.015} \\
\hline & Non-managers & 2.84 & 1.195 & & \\
\hline \multirow{2}{*}{ Q12 } & Managers & 3.38 & 1.454 & \multirow{2}{*}{2.467} & \\
\hline & Non-managers & 2.76 & 1.185 & & .015 \\
\hline & Managers & 3.66 & 1.335 & & \\
\hline Q13 & Non-managers & 3.05 & 1.201 & 2.473 & .015 \\
\hline & Managers & 3.91 & 1.228 & & \\
\hline Q15 & Non-managers & 3.03 & 1.187 & 3.664 & .000 \\
\hline Q16 & Managers & 4.00 & 1.047 & 4.024 & .000 \\
\hline
\end{tabular}




\begin{tabular}{|c|c|c|c|c|c|}
\hline & Non-managers & 3.13 & 1.176 & & \\
\hline \multirow[b]{2}{*}{ Q17 } & Managers & 3.44 & 1.390 & \multirow[b]{2}{*}{3.008} & \multirow[b]{2}{*}{.003} \\
\hline & Non-managers & 2.70 & 1.165 & & \\
\hline \multirow{2}{*}{ Q18 } & Managers & 3.56 & 1.480 & \multirow[b]{2}{*}{3.206} & \multirow[b]{2}{*}{.002} \\
\hline & Non-managers & 2.71 & 1.275 & & \\
\hline \multirow[b]{2}{*}{ Q19 } & Managers & 3.59 & 1.132 & \multirow[b]{2}{*}{3.086} & \multirow[b]{2}{*}{.003} \\
\hline & Non-managers & 2.89 & 1.139 & & \\
\hline \multirow[b]{2}{*}{ Q20 } & Managers & 3.31 & 1.401 & \multirow[b]{2}{*}{3.364} & \multirow[b]{2}{*}{.001} \\
\hline & Non-managers & 2.47 & 1.205 & & \\
\hline \multirow{2}{*}{ Q21 } & Managers & 3.34 & 1.359 & \multirow[b]{2}{*}{2.758} & \multirow[b]{2}{*}{.007} \\
\hline & \begin{tabular}{|l} 
Non-managers \\
\end{tabular} & 2.65 & 1.226 & & \\
\hline \multirow[b]{2}{*}{ Q22 } & Managers & 3.75 & 1.437 & \multirow[b]{2}{*}{2.768} & \multirow[b]{2}{*}{.006} \\
\hline & Non-managers & 3.03 & 1.261 & & \\
\hline
\end{tabular}

Note. Individual questionnaire items are specified in Table 1.

Table 6. Comparison of evaluation of corporate training from the viewpoint of the public and the private sector

\begin{tabular}{|c|c|c|c|c|c|}
\hline Q. items & Sector & Mean & $\begin{array}{l}\text { Standard } \\
\text { deviation }\end{array}$ & $\begin{array}{c}\text { Test } \\
\text { criterion }\end{array}$ & $\mathrm{p}$ \\
\hline \multirow{2}{*}{ Q1 } & Public & 3.58 & 1.318 & \multirow{2}{*}{2.309} & \multirow[b]{2}{*}{.022} \\
\hline & Private & 3.05 & 1.192 & & \\
\hline \multirow{2}{*}{ Q2 } & Public & 3.93 & 289 & \multirow{2}{*}{-3.130} & \multirow[b]{2}{*}{.002} \\
\hline & Private & 3.22 & .191 & & \\
\hline \multirow{2}{*}{ Q3 } & Public & 3.83 & 299 & \multirow{2}{*}{-2.343} & \multirow[b]{2}{*}{.020} \\
\hline & Private & 3.32 & 117 & & \\
\hline \multirow{2}{*}{ Q4 } & Public & 3.83 & 338 & \multirow{2}{*}{-2.535} & \multirow[b]{2}{*}{.012} \\
\hline & Private & 3.21 & 323 & & \\
\hline \multirow{2}{*}{ Q10 } & Publ & 3.48 & 154 & \multirow{2}{*}{-3.113} & \\
\hline & Priva & 2.80 & 177 & & \\
\hline \multirow{2}{*}{ Q13 } & Publi & 3.55 & 395 & \multirow{2}{*}{-2.256} & \multirow[b]{2}{*}{.026} \\
\hline & Private & 3.04 & .177 & & \\
\hline \multirow{2}{*}{ Q18 } & Public & 3.30 & 1.244 & \multirow{2}{*}{-2.176} & \multirow[b]{2}{*}{.033} \\
\hline & Private & 2.79 & 1.385 & & \\
\hline \multirow{2}{*}{ Q2 } & Public & 3.70 & 363 & \multirow{2}{*}{-2.760} & \multirow[b]{2}{*}{.006} \\
\hline & Private & 3.04 & 262 & & \\
\hline \multicolumn{6}{|l|}{ Factors } \\
\hline \multirow[b]{2}{*}{ F1 } & Public & 3.77 & 1.203 & \multirow{2}{*}{-3.128} & \multirow[b]{2}{*}{.002} \\
\hline & Private & 3.16 & 978 & & \\
\hline
\end{tabular}

Respondents working in the public sector scored higher in all corporate training evaluation items, from the perspective of which a statistically significant difference was found between the public sector employees and the private sector employees. Out of all analyzed factors, a statistically significant difference in the answers of the respondents was detected on in the factor F1 - Significance for the profession. In this case, the public sector employees had, again, higher scores.

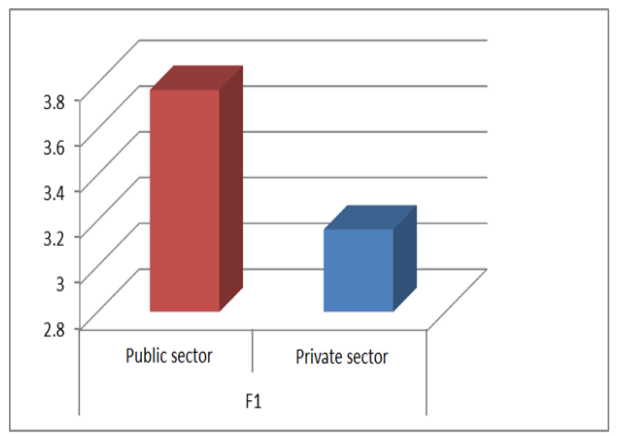

Figure 2. Average values of the factor F1 evaluation from the viewpoint of the public and the private sector 
The presented findings confirm that the public sector employees have a more intense perception of the need, significance and importance of corporate training, primarily from the viewpoint of carrying out their profession.

The public sector employees had higher scores also in some of the items related to the methods, forms of the training program and expectations. It supports the fact that they perceive more clearly the plan and organization of this training, which meets their expectations. The differences between the public sector employees and the private sector employees in evaluation of corporate training from the perspective of other items and factors were not proved to be statistically significant.

\section{Discussion}

The aforementioned research contains analyses of implementation of corporate training from various points of view. The starting point was to create and verify an own original methodology for evaluation of corporate training, identification and specification of the individual attributes of the internal structure of this process.

The subsequent implementation of this methodology enabled analyses of interconnections among the extracted factors of corporate training evaluation, as well as differences in evaluation of corporate training from the perspective of the work position and the work sector.

The research demonstrates that the utilized methodology enables extraction of 4 factors, which explain $65.6 \%$ of variance. Justification of the factor extraction was confirmed also by the Cronbach's alpha values which represent the required reliability degree of the items within the separate factors. The extracted factors were specified as: F1 - Significance for the profession, F2 - Benefits for the employees, F3 - Expectations of the employees, and F4 Satisfaction of the employees. Respondents with higher scores evaluate corporate training as clear, acceptable, and reasonable time-wise.

By means of this methodology, the existence of statistically significant correlations between all analyzed factors of the corporate training evaluation methodology was proved. Significance of the corporate training for the profession (F1) is closely connected to the benefits for the employees after completion of the training (F2), and also to their expectations (F3) and satisfaction with the training (F4). All four factors mutually inter-correlate at the significance level of 0.01 .
Identified were also significant differences in the analyzed factors and items, by means of which the corporate training was assessed from the viewpoint of the work position and the work sector. The aforementioned analyses display higher scores of managers as compared to the non-managers or efficient workers, as well as higher scores of the public sector employees as compared to the private sector ones.

These facts prove that managers and the public sector employees have a more intense perception of the need, significance and importance of corporate training, which is closely related to their work, career advancement, higher financial remuneration, and interpersonal relations.

\section{Conclusion}

The results and findings of the presented research confirm the fact that evaluation of corporate training is not homogeneous but it is possible to specify certain structural elements of this evaluation. The extracted and specified four factors may be considered to be one of the possible approaches to corporate training evaluation options.

Methodologically, the SBES questionnaire represents a concrete tool which may be used to gain feedback information about the corporate training. Its suitability for the corporate training evaluation was also confirmed by the results of the analysis of differences in evaluation of this education type between managers and non-managers.

It is crucial to highlight the fact that the principles of formulation of the SBES questionnaire may be utilized when creating any methodology for evaluation of any type of education.

The research results also confirmed the findings connected to specification of the external and internal factors of motivation to be educated. These findings correspond with those provided by Buckley and Caple [11], who specify two kinds of educational needs within the work process:

1. reaction needs (performance-related) $=$ when the performance at the workplace decreases due to insufficient education;

2. pro-action needs (taking over initiative, accepting responsibility) $=$ related to the strategies and the long-term goals of an organization as well as the human resource plan.

The issue of effective evaluation of corporate training is important also from the perspective of future motivation to be more educated. In this context it is possible to assume that employees who 
are content with their corporate training will continue with their further education in the future as well. On the contrary, those with a lower education level or those dissatisfied with the training will tend to avoid education as such and thus lose the opportunity to grow and advance.

Contributions brought by an effective corporate training described in this report correspond with those presented by other authors, for example Armstrong [12].

An important significance of effective corporate training of employees lies in an efficient evaluation of human capital and human potential which are crucial elements of competitiveness of an organization.

Finally, it is essential to accentuate that effective education and development of employees enables not only adaptation to changes in organizations, but also development of a work force which would propose and carry out these changes [4].

\section{Acknowledgements}

This research was supported by the grant project KEGA: 028PU-4/2014 [Coaching basics in management - innovation of the content and methods of teaching the subject; university textbook and methodological texts].

\section{References}

[1] Spector, P.E., Advanced Topics in Organization Behavior: Job satisfaction: Application, assessment, causes, and consequences, SAGE Publications, Thousand Oaks, CA, 1997.

[2] Barták, J., Jak vzdělávat dospělé [How to educate adults], Alfa, Praha, 197 p., ISBN 978-80-87197-12-7, 2008 .

[3] Russ-Eft, D.F., Evaluator competencies: Standards for the practice of evaluation in organizations, Jossey-Bass, San Francisco, 2008.

[4] W. Fitzgerald, "Training Versus Development", Training \& Development, 46(5), 1992, pp. 81-83.

[5] L.K. Savery, and J.A. Luks, "Does training influence outcomes of organizations? Some Australian evidence", Journal of Management Development, 23(2), 2004, pp. 119-124.

[6] L. Babić, and J. Boljanović, "Contemporary approach to education in organizations", Singidunum Journal of Applied Sciences, 10(1), 2013, pp. 46-53.
[7] Sadler-Smith, E., Learning and Development for Managers: Perspectives from Research and Practice, Wiley-Blackwell, 488 p., ISBN 978-1-4051-2982-4, 2005.

[8] Kachaňáková, A., O. Nachtmannová, and Z. Joniaková, Personálny manažment [Personal management], Iura Edition, Bratislava, 233 p., ISBN 97880-8078-192-7, 2008

[9] Vodák, J., and A. Kucharčíková, Efektivni vzdělávání zaměstnanců [Effective education of employees], Grada Publishing, Praha, 237 p., ISBN 978-80-247-651-8, 2011.

[10] Hroník, F., Rozvoj a vzděláváni pracovniků [Development and education of workers], Grada Publishing, Praha, 232 p., ISBN 978-80-247-1457-8, 2007.

[11] Buckley, R., and J. Caple, The Theory and Practice of Training (5th ed.), Kogan Page, London, 2007.

[12] Armstrong, M., A Handbook of human resource management practice (10th ed.), Kogan Page, London/Philadelphia, ISBN: 0749446315, 2006. 